\title{
Strategi Komunikasi Pemasaran RRI Malang dalam Upaya Pencapaian PNBP dan Meningkatkan Jumlah Pengiklan
}

\author{
Yulius $^{1}$, Herru Prasetya Widodo ${ }^{2}$ \\ 1,2Program Studi Ilmu Komunikasi, Universitas Tribhuwana Tunggadewi \\ Email: yuliusikom33@gmail.com
}

\begin{abstract}
RRI Malang as a Public Broadcasting Institution continues to survive amid intense competitions, with the demands to meet the target of achieving Non-Tax State Revenues (PNBP), which rely on the main source of revenue such as advertising but are bound by the Government Regulation No. 5 of 2015. The research aimed to find out how the marketing communication strategy of RRI Malang and the obstacles in implementing the strategy in an effort to achieve Non-Tax State Revenue (PNBP) and increase the number of Advertisers. This research used a descriptive qualitative research method with the data collection obtained from interviews and documents then collected and described. The result showed that the strategies applied by RRI Malang were market opportunity analysis and a competitive analysis which is summarized to an integrated marketing communication (IMC) which included: advertising in the form of price advertising, brand advertising and institutional advertising. A direct marketing through media channels such as catalogs, and telemarketing. The sales promotions were through broadcast programs, general and functional advertisements. The personal selling was through personal face-to-face communication. Furthermore, public relations (branding relations) activities were such as making press releases for each activity and becoming a media partner. The Barriers to the implementation of strategies were the limited funding sources and scope to collaborate with sponsors, advertisement selection was difficult to display discounts, because they were bound by the regulation No.5 of 2015 and lack of Human Resources (HR) and discrepancies between tasks and functions in the field of work.
\end{abstract}

Keywords: Marketing Communication Strategy, PNBP, Number of Advertisers

\begin{abstract}
Abstrak: RRI Malang sebagai Lembaga Penyiaran Publik tetap bertahan ditengah ketatnya persaingan, dengan tuntutan pemenuhan target pencapaian Penerimaan Negara Bukan Pajak (PNBP), yang mengandalkan sumber pendapatan utama yaitu iklan namun terikat oleh Peraturan Pemerintah No. 5 Tahun 2015. Penelitian bertujuan untuk mengetahui bagaimana strategi komunikasi pemasaran RRI Malang serta hambatan Penerapan strategi dalam upaya pencapaian Penerimaan Negara Bukan Pajak (PNBP) dan meningkatkan jumlah Pengiklan.Metode penelitian deskriptif kualitatifdari wawancara, danstudi dokumenlalu dihimpun dan dideskripsikan. (1) Strategi yang diterapkan RRI Malang yaitu analisis peluang pasar, dan analisis kompetitif. Dirangkum dalam intergrated marketing comunication (IMC) yang meliputi: periklanan (advertising) berupa price advertising, brand advertising dan intitusional advertising. Pemasaran langsung (direct marketing) lewat saluran media berupa katalog, dan telemarketing. Promosi penjualan (sales promotions) lewat siaran programa, iklan umum dan fungsional. Penjualan personal (personal selling) melalui komunikasi tatap muka. Selanjutnya hubungan masyarakat (public relations) aktivitas branding, membuat press release setiap hasil kegiatan dan menjadi pengelola media partner. (2) Hambatan penerapan strategi dalam pelaksanaan event terkait sumber dana dan ruang lingkupnya tidak bebas menggandeng sponsor, penjaringan Iklan sulit menampilkan diskon, karena terikat oleh aturan No.5 Tahun 2015 dan Sumber Daya Manusia (SDM) minim serta ditemukan ketidaksesuaian tugas dan fungsi pada bidang kerjanya.
\end{abstract}

Kata Kunci: Strategi Komunikasi Pemasaran, PNBP, Jumlah Pengiklan

\section{Pendahuluan}

Tingkat persaingan media khususnya lembaga penyiaran seperti stasiun radio saat ini cukup tinggi dalam merebut perhatian audien. Berawal dari kompetitifnya persaingan dalam merebut audien tetap dan menjadi sumber informasi yang praktis dan terjangkau. Setiap stasiun radio memiliki ciri khas masing-masing sesuai dengan segmentasinya. Di Indonesia 


\section{Jurnal Komunikasi Nusantara}

e-ISSN. 2685-7650

Vol. 1 No. 2 (2019), pp 64-75

DOI: https://doi.org/10.33366/jkn.v1i2.19

salah satunya bermula dari sejarah media informasi di era perjuangan yaitu dengan semboyan "Sekali di udara tetap di udara" semboyan yang tidak asing kita dengar ini adalah milik Radio Republik Indonesia dan biasa disingkat dengan RRI yang dikelola oleh pemerintah semboyan ini terus digunakan hingga saat ini.

Komunikasi pemasaran menjadi penting bagi perusahaan atau instansi saat dihadapkan pada beberapa permasalahan. Menurunnya pendapatan perusahaan yang disebabkan oleh minat konsumen terhadap suatu jasa, mengakibatkan lambatnya pertumbuhan dan perkembangan perusahaan atau instansi (Ekalista \& Hardianto, 2019). Banyak perusahaan mulai menseriusi adanya upaya mengintegrasikan berbagai kegiatan komunikasi pemasaran yang selama ini dilakukan terpisah. Karena itu strategi pemasaran perlu di kombinasikan sehingga tujuannya tercapai (Ginting, 2014)

Perusahaan-perusahaan itu mulai bergerak menuju proses yang disebut dengan komunikasi pemasaran terpadu yang mencakup upaya koordinasi dari berbagai elemen promosi dan kegiatan pemasaran lainnya yaitu bauran promosi pemasaran, sebagai berikut: Periklanan (Advertising), Pemasaran Langsung (direct Marketing), Promosi penjualan (sales promotion), Penjualan personal (personal selling), Hubungan masyarakat (public relations). Komunikasi pemasaran tetap harus memperhatikan pola-pola yang terencana sehingga tepat sasaran (Priansa, 2017:98).

Menurut Qorib dan Syahida (2018) pemasaran juga harus mengacu pada elemen-elemen komunikasi: pesan harus dipahami dan di make up sehingga menarik pengiklan. Qorib dan Syaidah yang meneliti tentang pariwisata dapat diaplikasikan juga untuk meningkatkan jumlah pengiklan. Menurut Widodo dan Yasak (2018) dalam penelitiannya yang diaplikasikan di pemasaran lovebird, dalam konteks ini, strategi pemasaran memegang peranan penting dalam pencapaian tujuan.

Sehingga strategi pemasaran harus diterapkan dengan prinsip-prinsip yang telah dicanangkan. Seorang pemsar juga harus memahami banyak aspek seperti persepsi, gaya hidup, sikap, dan budaya agar pemasaran efektif (Mardiana, 2013). Salah satu cara memenangkan persaingan adalah dengan informasi yang berkualitas, pemasaran produk yang baik, harga kompetitif, hingga tempat yang strategis (Rahastine, 2017). Strategi pemasaran sangat dibutuhkan dalam menjalankan usaha baik usaha yang lingkupnya besar, menengah, bahkan lingkup kecil. Sehingga RRI juga harus memperhatikan noise yang bisa menghambat upaya pencapaian PNBP.

RRI Malang menjadi radio yang hingga saat ini masih dekat dengan masyarakat. Sehingga banyakhal yang sangat menarik ditelusuri lebih mendalam, terutama berkaitan dengan strategi dalam bauran komunikasi pemasaran yang diterapkan sekaligus terkait sumber pendapatan dan pembiayaan di RRI Malang sesuai dengan yang dijelaskan dalam Peraturan Pemerintah Republik Indonesia Nomor 11 Tahun 2005 dan Undang-Undang 32 Tahun 2005 Pasal 14 Ayat (1) Tentang Penyiaran yaitu, sumber pendanaan berasal dari iuran penyiaran, Anggaran Pendapatan dan Belanja Negara (APBN) atau Anggaran Pendapatan dan Belanja Daerah (APBD), sumbangan masyarakat, siaran iklan dan usaha lain yang terkait dengan penyelenggaraan penyiaran. 


\section{Jurnal Komunikasi Nusantara}

e-ISSN. 2685-7650

Vol. 1 No. 2 (2019), pp 64-75

DOI: https://doi.org/10.33366/jkn.v1i2.19

Fokus dalam Pasal 14 Ayat (1) ini menjadi dasar dalam ruang gerak RRI Malang, permasalahan yang terjadi di RRI yaitu Lembaga Penyiaran Publik yang dikelola oleh pemerintah berbeda dengan radio swasta ketika dilihat dari segi iklan. Banyak sekali penyaringan iklan yang dilakukan oleh RRI, sedangkan iklan menjadi sumber pendapatan keuangan yang bisa digunakan untuk pengembangan dan menjadi hal yang sangat penting diperhatikan yaitu RRI Malang ini wajib melaksanakan pelaporan dan peyetoran uang setiap akhir tahun sesuai dengan UU No. 20 Tahun 1997 tentang Penerimaan Negara Bukan Pajak (PNBP).

Iklan menjadi sumber utama pemasukan dana untuk RRI dan Kas Negara. Namun yang menjadi permasalahan mendasar di RRI karena menjadi Radio Pemerintah terkait iklan banyak sekali persyaratan yang harus dipenuhi oleh pengiklan sehingga hal ini menyebabkan kurangnya pengiklan. Sesuai dengan Peraturan Pemerintah Republik Indonesia Nomor 11 Tahun 2005 Pasal 25 Tentang Siaran Iklan yang menjelaskan beberapa persyaratan atau ketentuan dalam pengajuan iklan seperti: materi siaran iklan harus sesuai etika periklanan, sesuai persyaratan KPI, dan ketentuan perundang-undangan yang berlaku, waktu siaran iklan niaga paling banyak 15\% (lima belas persen) untuk seluruh waktu siaran pada setiap harinya, dan materi siaran iklan wajib menggunakan sumber daya dalam negeri.

RRI Malang sebagai Lembaga Penyiaran Publik berdasarkan dengan Undang-Undang Nomor 11 Tahun 2005 Tentang Sumber Pembiayaan RRI dan Peraturan Pemerintah Republik Indonesia Nomor 5 Tahun 2015 Tentang Jenis Pajak dan Tarif Atas Jenis Penerimaan Negara Bukan Pajak yang berlaku pada Lembaga Penyiaran Publik, menjadi tuntutan bagi RRI dalam melaksanakan tugas untuk mencari iklan dan melakukan penyetoran ke kas Negara dalam bentuk pemasukan PNBP.

Hal yang sangat rumit dan menjadi fokus dalam sistem birokrasi yang ada di RRI Malang yaitu terkait dengan ketentuan peraturan yang mengikat karena upaya dalam penjaringan di lapangan menjadi kaku semua jenis transaksi iklan harus melewati biling Simponi kemudian kriteria iklan dan penyelenggaraan penyiarannya bersifat independen, netral, dan tidak komersil.

Permasalahan yang berhubungan dengan penjaringan calon pengiklan yang sulit dijangkau menjadi perhatian khusus hingga Mei 2019 data sebanyak 98 pengiklan yang terdiri dari iklan fungional dengan pendapatan sejumlah Rp. 63.293.000,- untuk target pencapaian PNBP 2019 sebesar Rp. 206.263.647,- dan jika tidak terpenuhi target tersebut maka akan dikenakan denda sesuai dengan pasal 21 Peraturan Direktur Utama Lembaga Penyiaran Publik Radio Republik Indonesia No. 09 Tahun 2017 yaitu menjelaskan Tentang Petunjuk Teknis Pegelolaan Penerimaan Negara Bukan Pajak Yang Berlaku pada Lembaga Penyiaran Publik Radio Republik Indonesia.

Dengan melihat realita dan tuntuntan yang sangat kompleks di RRI malang dalam memenuhi target penyetoran PNBP setiap tahun dan terkait upaya penyaringan Iklan. Maka, peneliti merasa tertarik untuk meneliti tentang "Strategi Komunikasi Pemasaran RRI Malang Dalam Upaya Pencapaian PNBP dan Meningkatkan Jumlah Pengiklan”. 


\section{Jurnal Komunikasi Nusantara}

e-ISSN. 2685-7650

Vol. 1 No. 2 (2019), pp 64-75

DOI: https://doi.org/10.33366/jkn.v1i2.19

\section{Metode Penelitian}

Penelitian ini menggunakan jenis penelitian deskriptif kualitatif. Penelitian ini digunakan dengan maksud untuk memahami lebih dalam tentang bagaimana "Strategi Komunikasi Pemasaran RRI Malang Dalam Upaya Pencapain PNBP dan Meningkatkan Jumlah Pengiklan". Menurut Emzir (2010:12), metode penelitian kualitatif adalah prosedur yang menghasilkan data-data secara deskrptif (penggambaran), yang meliputi kata-kata tertulis atau lisan dari orang-orang yang memahami obyek penelitian dan tataran an alias penelitian adalah deskrptif, Penelitian ini akan dilakukan pada Radio Republik Indonesia (RRI) Malang.

Penentuan informan dalam penelitian ini dilakukan secara segaja (purposive sampling). purposive sampling adalah teknik pengambilan sampel sumber data dengan pertimbangan tertentu (Moleong, 2015). Pertimbangan yang dimaksud adalah pertimbangan yang dilakukan oleh peneliti dengan menentukan informan yang oleh peneliti dianggap tahu mengenai hal yang diharapkan, atau informan yang memiliki kredibilitas yang bias dipercaya (Sugiyono 2015: 53-54). Dalam penelitian ini yang dijadikan informan yaitu Ibu W. Novia (Kasi Layanan dan Pengembangan Usaha), Pak Sucipto (Kasubsi LPU dan pengelola PNBP sekaligus Marketing Iklan),Pak Sujud (Marketing Event).

\section{Hasil dan Pembahasan}

\section{Strategi Komunikasi Pemasaran RRI Malang}

Strategi yang diterapkan yaitu strategi pemasaran dan proses target pasar. Kedua elemen pemasaran tersebut adalah analisis peluang pasar, dan analisis kompetitif.

\section{a. Analisis dan strategi pemasaran}

Setiap organisasi atau perusahaan yang ingin berhasil dalam pemasaran harus terlebih dahulu memiliki suatu rencana pemasaran strategis (strategic marketing plan) yang berfungsi sebagai panduan dalam menggunakan sumber daya yang dimiliki. Seperti yang kita ketahui bersama bahwa strategi pemasaran ditentukan berdasarkan analisis situasi, yaitu suatu studi terperinci mengenai kondisi pasar yang dihadapi perusahaan. Berdasarkan situasi ini RRI Malang mencoba memahami pasar yang mencakup peluang pasar dan tingkat persaingan di dalamnya.

\section{Analisis peluang pasar}

Peluang pasar merupakan salah satu kunci kerhasilan dan keberlangsungan suatu perusahaan begitu juga halnya dengan RRI sebagai Lembaga Penyiaran Publik peluang pasar menjadi tolok ukur dalam menyajikan iklan, berita, informasi ataupun siaran. Adapun yang menjadi peluang pasar bagi RRI Malang saat ini adalah penyiaran iklan yang didalamnya terdapat iklan fungsional dan iklan umum, penyampaian berita atau informasi yang akurat serta tetap menjaga keterbukaan terhadap masyarakat tanpa meninggalkan ataupun melupakan unsur budaya masyarakat yang ada dengan beberapa siaran programa.

\section{Analisis kompetitif}

Pesaing atau kompetitor RRI Malang yaitu adanya lembaga penyiaran swasta atau Radio swasta yang sama-sama menjadi media informasi bagi masyarakat. Adapun pesaing 


\section{Jurnal Komunikasi Nusantara}

e-ISSN. 2685-7650

Vol. 1 No. 2 (2019), pp 64-75

DOI: https://doi.org/10.33366/jkn.v1i2.19

dari RRI Malang adalah radio Kos Monita 95.4, KDS 8 sebagai pesaing saluran pro 1 RRI, dan radio City Guide, MFM Malang 101.3, Elfara FM 98.6, dan Kencaa FM 91.9 sebagai pesaing saluran pro 2 RRI Malang. Lembaga penyiaran swasta dapat bebas bergerak seperti penentuan harga, bonus dan diskon. Hal itu tidak menjadi masalah yang besar bagi RRI Malang karena sejak awal RRI sebagai lembaga penyiaran publik sudah memiliki nama yang besar dan dikenal oleh masyarakat luas serta memiliki strategi tersendiri dalam mempertahankan image-nya dengan karakteristik sebagai media pelestarian budaya.

\section{b. Proses Target Pasar}

Dalam Penetuan Target pasar harus mengawalinya dengan memperhatikan segmentasi pasar. Menurut, Kotler dan Amstrong (2006:121), segmentasi pasar merupakan aktifitas membagi-bagi pasar secara umum dari suatu produk ke dalam segmen pasar yang sifatnya khusus. Segmen pasar adalah golongan yang terdiri dari sekelompok pelanggan yang memiliki sekumpulan kebutuhan dan keinginan yang serupa atau sejenis.

Segmentasi pasar merupakan cara yang penting dalam mengembangkan program pemasaran. Segmentasi RRI Malang berdasarkan kebutuhan adalah mencakup semua kalangan berdasarkan klisifikasi pada program siaran, dalam hal klasifikasi ini RRI menetapkan segmen dengan sajian berita, informasi, hiburan berupa musik dan yang paling menojol dari RRI adalah Pro 2 saluran budaya dimana pada saat siaran berlansung adanya suguhan bahasa daerah, musik daerah serta proses kedekatannya lewat dialog interaktif. Sedangkan segmentasi geografisnya adalah dengan meperhatikan wilayah pada Zona C Kota Malang sehingga program Iklan difokuskan seperti Iklan Spot, Adlibs, dan dialog interaktif, karena kebanyak pengiklan lebih dominan pada iklan tersebut.

Kemudian dari analisis peluang pasar dan analisis Kompetitif dirangkum kedalam bauran komunikasi pemasaran terpadu atau intergrated marketing comunication (IMC) dengan menerapkan: Periklanan (Advertising), Pemasaran Langsung (direct Marketing), Promosi penjualan (sales promotion), Penjualan personal (personal selling), dan Hubungan masyarakat (public relations).

\section{Periklanan (Advertising)}

RRI Malang melakukan berbagai strategi komunikasi pemasaran sejak dari awal berdirinya. Dalam hal advertising, pada struktur organisasi LembagaPenyiaran Publik RRI Malang terdapat Kasi Layanan dan pengembangan usaha yang di dalamnya terdiri dari beberapa bidang seksi salah satunya yaitu marketing iklan, dimana marketing iklan mempunyai peran sebagai pengendali advertaising yang tujuannya yaitu untuk pencapaian target omset penjualan, pejaringan khususnya di bidang iklan, serta menjual produk iklan sesuai dengan standar harga yang ditetapkan. hal terkait strategi advertising terdapat 6 (enam) strategi yang meliputi: price advertising, brand advertising, Quality advertising, produk adverising insitusional advertising, dan prestige advertising namun yang dilakukan oleh RRI Malang ada 3 (Tiga) Bucari Alma (2014) dalam Priansa (2017:181) yaitu price advertising, brand advertising, dan intitusional advertising. Berkaitan dengan price adverising RRI malang melakukan pengolahan harga yang pada hasil akhir tidak bertentangan dengan Peraturan Pemerintah No. 5 Tahun 2015, hal ini menjadi sebuah tolok ukur penentu 


\section{Jurnal Komunikasi Nusantara}

e-ISSN. 2685-7650

Vol. 1 No. 2 (2019), pp 64-75

DOI: https://doi.org/10.33366/jkn.v1i2.19

untuk keberadaan RRI Malang. Selain Price advertising RRI Malang juga memperhatikan kegiatan brand advertising dengan menggunkan banner dan sarana programa, membangun kesan positif lewat advertising RRI Malang juga melakukan intitusional advertising seperti menjadi media Partner pada event yang melibatkan RRI.

Sarana advertising selanjutnya pada program siaran dimana ini adalah salah satu wadah untuk mempromosikan air time yang ditawarkan kepada calon klien. Karena melihat potensi omset yang cukup menguntungkan. Produk yang ditawarkan berupa Iklan Umum dan iklan fungsional , dimana iklan umum dimaksud berupa jasa penyewaan fasilitas atau iventaris, sedangkan iklan fungsional yaitu program siaran iklan yang terdiri dari 3 (tiga) Iklan program unggulannya yaitu Spot, Adlibs, dan Dialog Interaktif.

Berfokus pada Iklan Umum dan ke 3 (tiga)iklan fungsional unggulan yang ada di RRI Malang, sifat iklan fungsional tersebut secara singkat dapat dijelaskan sebagai berikut, Iklan Spot yaitu mengarahkan iklan dengan suara, sambil membacakan materi promosi, obrolan sesuai tema, dan dihiasa dengan efek atau background musik, Iklan kedua yaitu Adlibs jenis iklan yang disampaikan langsung oleh penyiar yang berisi materi siaran disela waktu programnya, kemudian iklan Dialog interaktif seperti halnya siaran langsung dengan melibatkan pengiklan pada acara siaran yang dipandu oleh penyiar secara bebas dengan melakukan tanya jawab ketika siaran berlangsung. Dari ketiga Iklan ini yang memiliki peningkatan paling banyak yaitu Iklan Spot bila di ukur berbanding dengan keseluruhan sekitar $60 \%$.

Kemudian terkait intitusional advertising yaitu lewat aplikasi RRI Go play, pemasangan banner Programa 1, Programa 2 Saluran Budaya (SB), dan Programa 3 Siaran Nasional yaitu terkait dengan News Berita. Dari setiap banner programa ini disesuaikan dengan kegiatan yang berlangsung untuk media partner dalam event yang nantinya akan dishare dan diolah oleh bagian penyiaran untuk di publikasikan, dan terkait logo RRI pada setiap kegiatan yang melibatkan diwajibkan untuk dipasang dan dimunculkan pada banner kegiatan, baik itu kegiatan internal maupun eksternal.

Kegiatan internal RRI Secara terjadwal dilaksanakan, seperti partisipasi RRI pada kegiatan-kegiatan Nasional contoh: pemasangan banner arus balik pada saat bulan suci rahmadan, dan 2 (dua) fokus kegiatan lainnya yaitu Pekan Tilawatil Qur'an (PTQ) dan Bintang Radio. Strategi inilah yang secara kontinu dilaksanakan RRI dalam upayanya untuk promosi dan penjaringan lewat advertising yang di telah direncanakan dan diterapkan.

\section{Pemasaran Langsung (Direct Marketing)}

Sarana Direct marketing ini menjadi suatu pendukung dalam menjaring klien dan sponsor perusahaan kemudian dengan melihat kebutuhan pada event maka penjaringan dilakukan harus mendekati dan adanya keterkaitan antara event dan produk sponsor seperti dalam acara jalan Sehat RRI contohnya dikirimlah surat atau proposal kegiatan kepada pocari sweet untuk berkenan menjadi sponsor dalam kegiatan tersebut, karena ketika melakukan kegiatan dalam halnya olahraga pasti mengalami haus dan kelelahan maka ini menjadi pertimbanagn penjaringan oleh direct marketing selanjutnya menjaring PMI untuk pengobatan gratis dilanjukan dengan kegiatan donor darah target serta kriteria calon 


\section{Jurnal Komunikasi Nusantara}

e-ISSN. 2685-7650

Vol. 1 No. 2 (2019), pp 64-75

DOI: https://doi.org/10.33366/jkn.v1i2.19

pengiklan, pengiklan dan sponsor ini lah yang harus diperhatikan. kemudian pertimbangan ini dilanjukan dengan pihak marketing Iklan dan marketing event agar terjadinya koordinasi yang sesuai dengan ketentuan Peraturan yang diberlakukan pada event dan iklan dalam kaitannya dengan PNBP. Dengan demikian RRI Malang menerapakan media direct marketing seperti katalog melaui pengiriman surat edaran atau undangan dan proposal kepada sponsor dan saluran umpan balik juga di lakukan dengan menggunakan telemarketing seperti via telpon, dan akun instgram programa sekaligus akun official resmi RRI Malang.

\section{Promosi Penjualan (Salles Promotion)}

Sarana komunikasi pemasaran yang digunakan RRI Malang dalam melaksanakan aktivitas-aktivitas strategi komunikasi pemasaran yaitu memberikan promosi, bonus, atau discount kepada calon pengiklan, ini berlaku sebelum dikeluarkan Peraturan Pemerintah No. 5 Tahun 2015. Awal di bulan April 2015, semua jenis aktivitas sales promotion dalam kenyataannya hal terkait promosi, bonus, atau discount ini tidak dapat dijalan karena melanggar Peraturan pemerintah No.5 Tahun 2015 tentang aturan Iklan dan PNBP.

Dalam peraturan tersebut tidak mencantumkan terkait adanya bonus atau discount pada pelaksanaannya dan ketentuan harga sudah tertera sekaligus bersifat mutlak dari Mentri Keuangan. Maka dari permasalah tersebut Strategi yang dilakasanakan RRI Malang khususnya sales promotion antara lain dimaksimalkan salah satunya dengan melalui event seperti Bintang Radio yang akan dilaksanakan pada bulan Agustus 2019 deskripsi event adanya penjaringan sponsor dan target peserta se- Malang Raya dengan penyebaran undangan ke universitas dan sekolah-sekolah, dari event ini promosi akan di laksanakan dengan live sekaligus menghadirkan pihak sponsor dengan ketentuan dan persyaratan khusus sebelum melakukan kegiatan atau event, pada umumnya di mulai sejak dikelurkan momerandum of understanding (MoU) yang biasanya terdaftar apa yang akan di perbolehkan untuk di iklankan atau di publikasi.

Demi menjaga hubungan jangka panjang sales promotion menetapkan strategi dalam bentuk penawaran kepada calon pengiklan dan pengiklan dalam hal ini proses lobi dan negosiasi akan terjadi. Hal ini dimaksud adalah terjadinya permintaan seperti penambahan jam siar dan sebagainya oleh pengiklan, tentu hal ini harus dipertimbangkan maka alternatif yang dilakukan yaitu menetapkan dan mengecek kembali kategori pelanggan tetap dan yang tidak maka pertimbangan berupa strateginya agar tidak bertentangan dengan Peraturan Pemerintah No. 5 Tahun 2015 yaitu alternatif penawaran sebagai media partner mendukung kegiatan dan ini lah strategi sampai hari ini yang bisa dilakukan RRI Malang, perbedaan media partner dan Iklan karena menyangkut kesinambungan peran untuk branding yang bersentuhan langsung dengan public relations maka ini diperbolehkan. Kemudian strategi lain yang diterapkan oleh sales promotion berikutnya yaitu mengutamakan cara dan komunikasi yang baik serta menawarkan konsep ataupun ide yang menarik, kreatif serta unik untuk menarik perhatian sponsor dalam pelaksanaan sales promotion. Karena apabila sponsor merasa puas, mereka akan melakukan kerja sama secara kontinu, ini menjadi tolak ukur untuk melihat tingkat keberhasilan sales promotion. 


\section{Jurnal Komunikasi Nusantara}

e-ISSN. 2685-7650

Vol. 1 No. 2 (2019), pp 64-75

DOI: https://doi.org/10.33366/jkn.v1i2.19

\section{Penjualan Personal (Personal Selling)}

Upaya yang dilakukan oleh RRI Malang tidak hanya melakukan pendekatan melalui iklan saja, mereka juga melibatkan hubungan emosional. Penekanan dalam startegi penjualan langsung (personal selling) yaitu dengan terjun langsung bertemu melakukan lobi dan negosiasi untuk menerapakan ciri-ciri dalam integrated marketing comunication (IMC), dalam konteks komunikasi persuasif yang responnya di dapatkan secara cepat. Upaya strategi komunikasi pemasaran dengan menganalisis pelanggang lewat pelaksanaan peran personal selling tersebut terjadinya penawaran dan yang paling menonjol dari strategi ini yaitu dengan memberikan berbagai alternatif dalam bentuk persuasif.

Hal ini salah satunya dilakukan ketika melobi pihak sponsor untuk memberikan kontribusi, produk atau jasa, dalam upayanya personal selling bagian dari marketing iklan dan marketing event terkait konteks event seperti kegiatan Jalan Sehat RRI, ini menjadi perhatian penerapan personal selling untuk proses persiapan event dengan melakukan penawaran dan penjaringan sponsor. Yang menjadi pelaku dari personal selling pada RRI Malang ini adalah bagian dari marketing event seperti halnya dalam pembuatan seminar- seminar salah satunya adalah acara Hari Kartini pada 21 April 2019 dengan tema "Kartini Masa Kini Siap Mengawal NKRI". Tolok ukur pencapaian dalam penjualan langsung ini adalah dengan adanya laporan setiap hari oleh pelaku marketing dilapangan. Pentingnya marketing event ini juga sesuai dengan penelitian sebelumnya (Olla, Yasak, 2018) yang menyatakan bahwa event memiliki peran yang besar bagi RRI dalam menggandeng pihak-pihak penyelenggara dan menentukan sukses tidaknya sebuah event.

\section{Hubungan Masyarakat (Public relations)}

Strategi yang diterapkan oleh RRI Malang dalam upayanya mencapai PNBP dan meningkatkan jumlah pengiklan diupayakan lewat tugas dan fungsi dari semua bidang yang ada seperti marketing, bagian penyiaran dan lainya. Dalam penerapan tugas dan fungsi dari public relations yaitu sarana atau media penghubung di internal dan eksternal di munculkan bidang Kumunikasi Publik yang sebelumnya lagi dengan nama Bagian Pencitraan. Berdasarkan tugas dan fungsinya peran Public Relations RRI memiliki tugas sebagai branding hal ini dilihat dari segi pekerjaannya sebagai penyaring dan wadah penerimaan laporan kegiatan dijelaskan dengan ketentuan penghubung antara semua marketing dan yang akan melanjutkan kriteria Siaran dan media partner berdasarkan event kepada setiap programa yang ada di RRI yang terdiri atas 3 programa, yaitu Pro 1, Pro 2 atau Saluran Budaya (SB), dan Pro 3 News Berita. Public relations memegagang peran sebagai penerima jasa media partner dalam konteks mendukung kegiatan dengan mefasilitasi $X$ - banner, umbul-umbul dan Program siaran berdasarkan ketentuan dan kriteria kegiatan yang di tuangkan dalam surat kesepatan atau Memorandum of Understanding (MoU).

Selain itu peran public relations juga harus mengumpulkan hasil dokumentsi kegiatan, mencatat dan mengamati analisis strategi peluang pasar dan kompetitor disetiap programa seperti kompetitor Pro 1 yaitu Kos Monita 95.4, KDS 8 , dan Pro 2 seperti City Guide, MFM Malang 101.3, Elfara FM 98.6, dan Kencaa FM 91.9. Dari hasil tersebut menjadi kajian dalam mengkordinasikan program bagian branding ketika dilapangan. Dan menempatkan Press 


\section{Jurnal Komunikasi Nusantara}

e-ISSN. 2685-7650

Vol. 1 No. 2 (2019), pp 64-75

DOI: https://doi.org/10.33366/jkn.v1i2.19

release yang bersumber dari marketing iklan dan marketing event untuk diserahkan kepada bagaian penyiaran disetiap programa yang berdasarkan hasil penyaringan.

Melihat tantangan dan persaingan di dalam tugas dan fungsinya, peran tugas public relations RRI Malang tergabung dalam satu kesatuan tugas di bidang Lembaga Pengembangan Usaha untuk menjaga citra lembaga sebagai komunikasi publik dan pada peran pemasarannya melakukan promosi dan mengkordinir media partner di beberapa kegiatan yang tujuannya adalah untuk membangun relasi dan kedekatannya dengan masyarakat serta branding.

Penerapan strategi komunikasi pemasaran RRI Malang secara terencana sesuai yang telah di jelaskan dengan memperhatikan komponen-komponen dalam bauran pemasaran yang tergabung dalam Integetad Marketing Communication yang meliputi: Periklanan (Advertising), Pemasaran Langsung (direct Marketing), Promosi penjualan (sales promotion), Penjualan personal (personal selling), Hubungan masyarakat (public relations).Ini dilaksanakan langsung oleh marketing yang terdiri dari marketing iklan, dan marketing event, yang secara struktural tergabung ke dalam lembaga pengembangan usaha. Dari keseluruhan strategi yang telah diterapkan dalam upaya pencapaian PNBP dan meningkatkan jumlah pengiklan, sudah sesuai pada sasarannya, namun dari penjaringan tersebut masih belum maksimal, untuk memenuhi pencapaian target penyetoran PNBP.

Komponen strategi yang telah terencana menjadi tolok ukur, terlihat jelas pada tahun 2018 target pencapaian PNBP terlampir Rp. 223.006.563,- dengan upaya yang sudah dimaksimalkan melalui iklan fungional atau iklan utama RRI dari keseluruhan pendapatan yang diperoleh dari event dan program siaran dengan total hasil Rp. 127.588.500,- dari hasil tersebut menunjukan bahwa pencapaian dari strategi pemasaran masih mengalami kekurangan dan belum efektif. Sehingga untuk menjawab tuntutan tersebut RRI harus menemukan solusi dalam menjawab Peraturan Direktur Utama Lembaga Penyiaran Publik Radio Republik Indonesia No. 09 Tahun 2017 pasal 21 yang menjelaskan terkait dengan denda serta sanksi jika tidak terpenuhinya target pencapaian PNBP, berkaca dari tuntutan tersebut RRI memfokuskan upaya lainnya dengan memperhatikan fasilitas atau inventaris yang dijadikan iklan umum yang sifatnya diluar program siaran menjadi sebuah solusi tepatnya pada tahun 2018 dengan menghasilkan pemasukan sebesar Rp. 269.305.000,- sehingga upaya ini mampu menutupi kekurangan terkait penyetoran PNBP dengan total keseluruhan Rp. 353.754.000,mampu melampaui target yang di tentukan oleh Direktur Utama Lembaga Penyiaran Publik Radio Republik Indonesia.

Berdasarkan hasil tersebut strategi tidak dapat dikatakan efektif karena fokus dalam lembaga penyiaran publik sumber pendapatan utama adalah iklan dan siaran. Namun dari hasil akhir belum mampu merealisasikan pencapaian target dan hingga Mei 2019 data terlampir sebesar Rp. 63.289.000,- dengan target pencapaian PNBP 2019 sebesar Rp. 206.263.647,-. Maka dari total keseluruhan pencapaian iklan utama belum mampu merealisasikan PNBP sehingga strategi pemasaran masih perlu ditingkatkan dan dievaluasi. 


\section{Jurnal Komunikasi Nusantara}

e-ISSN. 2685-7650

Vol. 1 No. 2 (2019), pp 64-75

DOI: https://doi.org/10.33366/jkn.v1i2.19

\section{Hambatan Penerapan Strategi Komunikasi Pemasaran RRI Malang}

Berdasarkan analisis strategi yang diterapkan RRI Malang yaitu terbagi atas 2 (dua) bagian yaitu analisis strategi pemasaran dan proses target pasar. Kedua elemen pemasaran tersebut adalah analisis peluang pasar, dan analisis kompetitif, yang dirangkum kompleks kedalam bauran komunikasi pemasaran terpadu atau intergrated marketing comunication (IMC) dengan menerapkan: Periklanan (Advertising), Pemasaran Langsung (direct Marketing), Promosi penjualan (sales promotion), Penjualan personal (personal selling), Hubungan masyarakat (public relations).

Hasil tersebut tidak dapat dipungkiri bahwa strategi yang sudah diterapkan memliki hambatan. Beberapa hambatan penerapan strategi komunikasi pemasaran RRI Malang dalam pencapaian PNBP dan peningkatan jumlah pengiklan yaitu, pertama dalam pelaksanaan event dari strategi komunikasi pemasaran yang telah direncanakan tentunya ada tantangan yang dihadapi biasanya mengenai dana dan sponsor dimana event menjadi sarana promosi paling efektif namun sumber pendanaan yang sulit didapatkan dan dicairkan.

Faktor utama yang menjadi tantangan yaitu pengalokasian dana sangat sulit di lakukan dan karena minimnya pendapatan namun harus adanya penyetoran, terkait tim dibidang seksi marketing event juga terdapat kendala karena dari beberapa kegiatan biasanya harus mengeluarkan biaya pribadi untuk dijadikan biaya operasional, ini menjadi hambatan untuk bergerak karena mengakibatkan adanya pembatas ruang gerak akhirnya diabaikan, selanjutnya jumlah personil kurang sedangkan secara struktural dalam birokrasi Sumber Daya Manusia (SDM) nya sangat banyak namun menjadi persoalan, sehingga terjadi ketergantungan misalkan seperti urusan pemasaran merangkap sebagai pengelola PNBP selanjutnya penjaringan dihadapkan pada lintas seksi dalam Lembaga Pengembangan usaha yang seharusnya fokus sebagai bagian dari pemasaran namun satu bidang atau seksi merangkap tugas sebagai Humas secara keseluruhan untuk branding.

Persoalan lain dalam bidang advertising yang bersentuhan langsung dengan bidang atau seksi marketing iklan. Banyak sekali hambatan yang harus di hadapi oleh marketing pertama, kerja harus ditarget dengan pencapaian yang telah ada sesuai pendapatan setiap bulannya, minimnya biaya operasional, sulit untuk menyampaikan strategi seperti pembuatan diskon atau bonus untuk menarik minat klien, tingkat SDM yang minim, seperti kekuraangan tim dilapangan sehingga berdampak tidak efektif dari segi penjaringan. Selain itu setiap transaksi dalm penjaringan iklan harus melalui presedur dan ketentuan pada Peraturan Pemerintah No.5 Tahun 2015. Korelasi hambatan yang di alami oleh marketing biasanya terlihat jelas pada pelaksanaan event, dapat diukur dengan memperhatikan tingkat dan jumlah peserta, kemudian jumlah sponsor yang mendukung kegiatan.

Secara umum hambatan penerapan strategi komunikasi pemasaran yang dialami oleh RRI Malang, yaitu sejak dikeluarkannya Peraturan Pemerintah No. 5 Tahun 2015, sebelumnya RRI Malang tidak dihadapkan pada aturan yang mengikat secara ketat dalam konteks penjaringan iklan sehingga proses pengelolaan anggaran bisa secara bebas diolah dan dikembangkan untuk memaksimalkan, dalam upaya pengembangan, peningkatan biaya operasional dan sebagainya. Namun semenjak adanya aturan terkait untuk tarif atau transaksi 


\section{Jurnal Komunikasi Nusantara}

e-ISSN. 2685-7650

Vol. 1 No. 2 (2019), pp 64-75

DOI: https://doi.org/10.33366/jkn.v1i2.19

pembayaran Iklan mengenai ketentuan dan nominalnya sudah terlampir di dalam peraturan dan bersifat mutlak menjadikan RRI harus memaksimalkan segala aktivitasnya.

Bentuk transaksi pembayaran yaitu lewat Biling Simponi atau alat perekam dipantau oleh Mentri Keuagan Republik Indonesia, yang langsung dikirim ke Kas Negara dengan nominal sesuai pada Peraturan Pemerintah No. 5 Tahun 2015 Tentang Jenis dan Tarif Atas penerimaan Negara Bukan Pajak. Dengan adanya Peraturan Pemerintah No. 5 Tahun 2015, semua sistem yang ada di dalam RRI Malang berubah, SDM harus beradaptasi dengan peraturan yang diterapkan, terjadinya perombakan Struktural dikarenakan ketidaksesuaian dengan bidang kerjanya, diwajibkan kepada seksi marketing untuk mempelajari dan memberikan informasi secara kontinu dalam bentuk sosialisasi Peraturan terkait kepada klien, mulai dari teknis pembayaran, ketentuan dan persyaratan iklan serta wajib bayar PNBP oleh RRI sesuai Peraturan Direktur Utama Lembaga Penyiran Publik No. 9 Tahun 2017.

Jumlah Pencapaian harus terpenuhi karena target dan adanya sanksi sesuai pasal 21 mengenai keterlambatan dan kekurangan penyetoran PNBP. RRI Malang mengalami kekakuan dalam bentuk strategi yang diterapkan dengan kompetitifnya persaingan yang akhirnya terjadi pertentangan yang rumit terhadap Peraturan Pemerintah No. 5 Tahun 2015.

\section{Kesimpulan}

Strategi yang diterapkan RRI Malang terbagi atas 2 (dua) bagian yaitu analisis strategi pemasaran dan proses target pasar. Kedua elemen pemasaran tersebut adalah analisis peluang pasar, dan analisis kompetitif, yang dirangkum kompleks kedalam bauran komunikasi pemasaran terpadu atau intergrated marketing comunication (IMC) dengan menerapkan: Periklanan (Advertising) yaitu: price advertising, brand advertising dan institusional advertising. Pemasaran Langsung (direct Marketing), yaitu melaui:Saluran media berupa katalog, dengan bentuk surat undangan, proposal, pamflet dan telemarketing, seperti via telpon dan akun official. Promosi penjualan (sales promotion), dengan melaui siaran programa, Iklan umum dan iklan fungsional. Penjualan personal (personal selling), dilakukan dengan komunikasi tatap muka atau terjun langsung bertemu klien.Hubungan masyarakat (public relations), sebagai branding dengan membuat laporan Press release setiap hasil kegiatan dan menjadi pengelola sarana media partner untuk mendukung aktivitas marketing dilapangan. Strategi tersebut terukur belum efektif dalam upaya pencapaian PNBP, sehingga dalam memaksimalkan target pencapaian RRI Malang hingga saat ini masih mengandalkan Iklan umum yaitu lewat penyewaan fasilitas yang dimiliki. Hambatan dalam penerapan strategi komunikasi pemasaran adalah pelaksanaan event terkait sumber dana, SDM yang minim dan ditemukan ketidaksesuaian tugas serta fungsi pada bidang kerja, penjaringan iklan sulit menampilkan besaran diskon untuk menarik minat calon pengiklan, karena keterikatan oleh peraturan Pemerintah No.5 Tahun 2015. 


\section{Jurnal Komunikasi Nusantara}

e-ISSN. 2685-7650

Vol. 1 No. 2 (2019), pp 64-75

DOI: https://doi.org/10.33366/jkn.v1i2.19

\section{Daftar Pustaka}

Ekalista, P. \& Hardianto, W. T. (2019). Strategi Komunikasi Pemasaran Hotel Kartika Graha Malang Dalam Meningkatkan Jumlah Pengunjung. Jurnal Komunikasi Nusantara, 1 (2), 20-26.

Emzir. (2010). Metode penelitian kualitatif. Jakarta: PT. Rajagrafindo

Ginting, Ina Veronika. (2014). Strategi Komunikasi Pemasaran PT Cipaganti dalam Meningkatkan Kepariwisataan di Jawa Barat. Jurnal Manajemen Resort dan Leisure, 11 (2), 87-94.

Kotler, A. (2016). Manajemen Pemasaran. Jakarta:Prenada

Moleong, L. J. (2015). Metodologi Penelitian Kualitatif. Ed. Revisi. Bandung: PT. Remaja Rosdakarya.

Olla, Y. O., dan Yasak, E. M. (2018). Strategi Komunikasi Pemasaran RRI Malang DalamPeningkatan Jumlah Pengiklan. Jurnal JISIP, 7 (1), 77-87.

Peraturan Pemerintah Republik Indonesia Nomor 11 Tahun 2005 Tentang Peyelenggaran Penyiaran Publik

Peraturan Pemerintah Rpublik Indonesia Nomor 5 Tahun 2015 Tentang Jenis dan Tarif Atas Jenis Penerimaan Negara Bukan Pajak yang berlaku pada Lembaga Penyiaran Publik Radio Republik Indonesia

Peraturan Direktur Utama Lembaga Penyiaran Publik Radio Republik Indonesia No. 09 Tahun 2017 Tentang Petunjuk Teknis Pegelolaan Penerimaan Negara Bukan Pajak Yang Berlaku pada Lembaga Penyiaran Publik Radio Republik Indonesia.

Priansa. (2017). Komunikasi Pemasaran Terpadu. Bandung. CV Pustaka Setia

Rahastine, MR. (2017). Strategi Komunikasi Pemasaran The Flat Shoes Company dalam Menghadapi Persaingan Bisnis Online Shopping di Indonesia. Jurnal Komunikasi, 3 (2), 81-91.

Qorib, F dan Syahida, AR. 2018. Pola Komunikasi Pariwisata Pengerajin Keramik Di Kelurahan Dinoyo Kota Malang. Jurnal Refomasi, 8, (2), 151-161.

Mardiana, S. (2013). Peranan Komunikasi Pemasaran dalam Membentuk Perilaku Konsumen. Jurnal Komunikasi. 2 (2), 40-46.

Sugiyono. (2015). Metode Penelitian Pendidikan Kualitatif,Dan $R \& D$ : Bandung Alfabeta.

Widodo, H. P., dan Yasak, E. M. (2018). Strategi Komunikasi Pemasaran Peternak Lovebird dalam Meningkatkan Loyalitas Pelanggan. Jurnal Reformasi, 8 (1), 1-7.

Undang-Undang Republik Indonesia No.32 Tahun 2002. 